\title{
NOTES ON TWO GREEN PLANKTON FOUND IN BANGLADESH
}

\author{
A.K.M. Nurul Islam and Md. Almujaddade Alfasane \\ Department of Botany, University of Dhaka, Dhaka-1000, Bangladesh \\ Key words: Green planktonic algae, Chlorococcales, Bangladesh
}

The paper deals with two green plankton algae belonging to Chlorococcales, recently collected in Bangladesh. One of them was reported as Treubaria umbrina (Smith) Fott and Kov. by Islam and Alfasane (2001), and the other one, not yet recorded for Bangladesh, looks somewhat like a member of Echinosphaerella Smith. The systematic position and nomenclature of the former taxon has become somewhat controversial and the latter is yet to be identified. These are now discussed below.

1. Pachycladella umbrina (Smith) Silva (Basionym: Pachycladon umbrinus Smith,

G.M. 1924; Synonym: Treubaria umbrina (Smith) Fott and Kovacik 1975). (Figs. 1-4)

Silva (1970) changed the generic name Pachycladon as this name was preoccupied and renamed it as Pachycladella. Fott and Kovacik (1975) considered P. umbrinus under the genus Treubaria Bern., whereas Reymond et al. (1992) agreed to keep it under Pachycladella. Earlier, we have identified our material as Treubaria umbrina, which we think was not justified and now it needs correction. Smith (1950) while describing Pachycladon states that "this genus has considerable resemblance to Treubaria, it differs in shape of the cell, in nature of appendages and in the chloroplast”. The cells are spherical without a gelatinous envelop, the wall bears four stout appendages that are usually quadrately arranged, rarely pyramidate. The appendages are dark brown in colour and tapered from a broad base to blunt or bifurcate apex. Accordingly, there should not be any controversy regarding the differences between these two genera and thus, now we prefer to reidentify this taxon as Pachycladella umbrina (Smith) Silva.

The material of this taxon was collected from a large pond near Baroauliar mazar in Barisal district on 31 July 2000; water pH 6.8 and temperature $29^{\circ} \mathrm{C}$.

2. Echinosphaerella-like species

(Figs. 5-9)

Cells spherical, solitary, planktonic, without any gelatinous sheath; cell wall thin, incompletely covered by stout hyaline spines with broad base, and sharply acute apex; chloroplast and pyrenoid not clearly seen; cell diam. 27-30 $\mu \mathrm{m}$; spines 12-21 $\mu \mathrm{m}$ long; base of spines 3-8 $\mu \mathrm{m}$ broad.

The material was collected from the sewage pond at Pagla, Narayanganj on 15 July 2004; water $\mathrm{pH} 7.75$ and temperature $31.5^{\circ} \mathrm{C}$.

The cell structure apparently looks like the zygospores of some desmids, or some volvocalean algae, but in the collection not a single cell of these groups of green algae 
could be found and thus we may consider these cells as the vegetative stage of any taxon. Until further studies we provisionally place it under the genus Echinosphaerella. Hindak and M.-Gouni (1990) while describing Treubaria triappendiculata mentioned that besides 3-4 spined cells of this taxon, there are few multispined (7-16 spines or upto 50 spines) Echinosphaerella - like cells, were also present in the same collection, and they
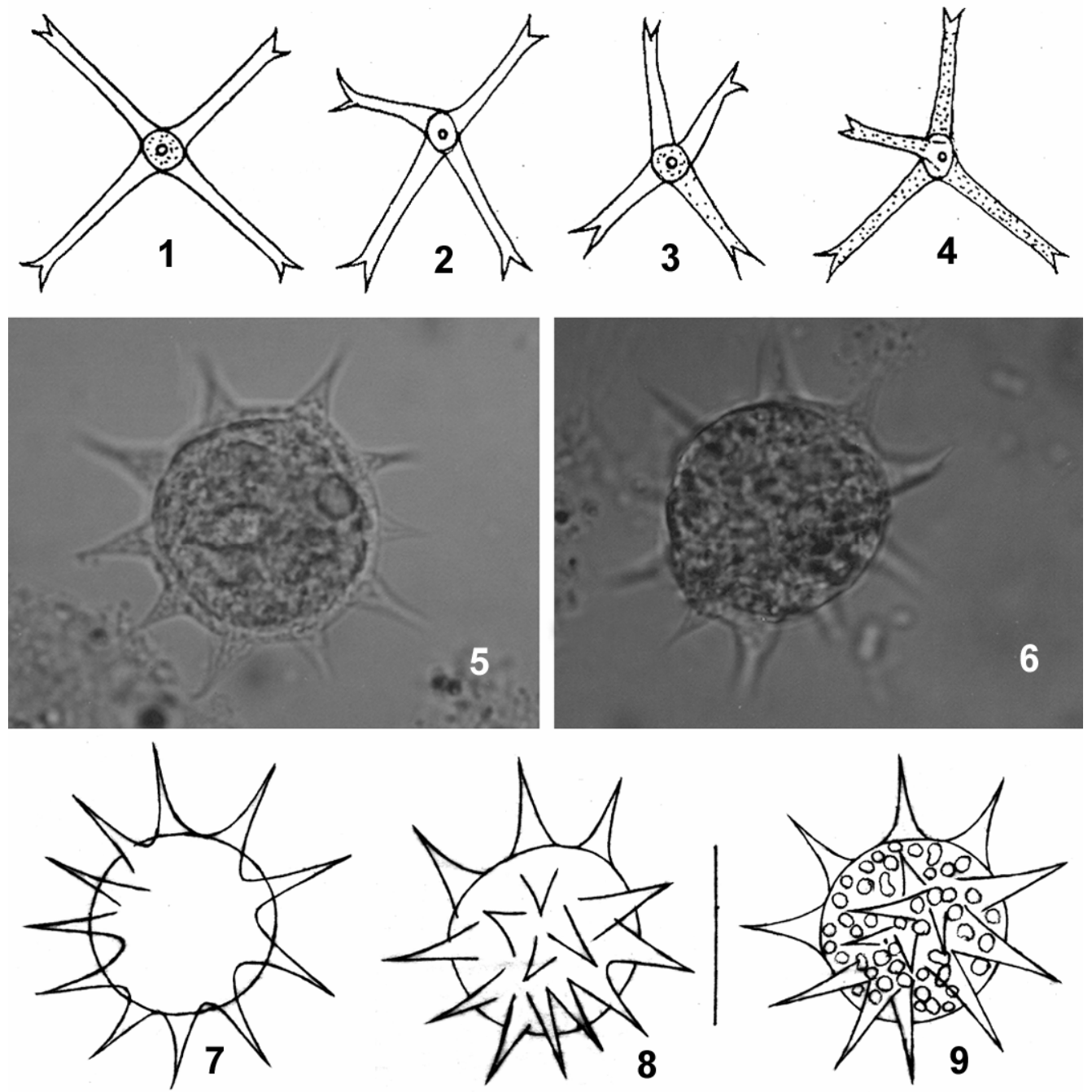

Plate 1 (Figs. 1-9)

Figs. 1-4. Pachycladella umbrina (Smith) Silva. 5-6. Echinosphaerella - like cells (Photomicrophs). 7-9. Echinosphaerella - like cells (Camera lucida drawings). (Scale $=30 \mu \mathrm{m}$ ).

considered these latter cells also as T. triappendiculata. In the latter cells the many spines, however, did not cover the cells completely. Recently we have found several planktonic unicellular structures with several spines on the cell wall. The spines are more 
or less similar to some of the cells as shown by Hindak and M.-Gouni (Fig. 2, No. 1 ( $3^{\text {rd }}$ one). The base of the spines in our cells is broad and the apex is sharply pointed. Most of the spines in our cells are not too long. In general our cells are more or less similar to the cells as shown by Hindak and M.-Gouni but we think that our cells are close to Echinosphaerella rather than to Treubaria.

\section{References}

Fott, B. and Kovacik, L. 1975. Über die Gattung Treubaria (Chlorococcales, Chlorophyceae). Preslia 47: 305-316.

Hindak, P. and M.-Gouni, M.T. 1990. Planktic coccal and trichal green algae of Lake Volir, Greece. Folia Geobot. Phyto-Taxonomica. 25(2): 159-195.

Islam, A.K.M. Nurul and Alfasane, M.A. 2001. New records of some freshwater planktonic algae for Bangladesh: Species of Treubaria, Goniochloris, Tetraedriella and Tetraplektron. Bangladesh J. Bot. 30(2): 131-134.

Reymond, O.L., Yamagishi, T. and Druart, J.-C. 1992. Morphological and taxonomical assessment of former and present records of Pachycladella umbrina and P. zatoriensis (Green alga, Chlorococcales). Cryptogamie, Algol. 13(2): 93-107.

Smith, G.M. 1924. Ecology of the plankton algae in Palisades Interstate Park, including the relation of control methods to fish culture. Roosvelt Wild Life Bulletin. 2: 95-195.

Smith, G.M. 1950. The fresh-water algae of the united States. $2^{\text {nd }}$ edn., McGraw-Hill, New York. pp. 719. 